Received: 12.05 .2020

Accepted: 11.10.2020

Published Online: 06.09.2021

DOI: 10.18613/deudfd.736015

Research Article

Dokuz Eylül University Maritime Faculty Journal

Special Issue pp:17-36

E-ISSN: 2458-9942

\title{
SEAPORT SUPPLY CHAIN ORIENTATION AND ITS IMPACT ON PERFORMANCE
}

\author{
Hassan Abdi HASSAN ${ }^{1}$ \\ Onur ÇETIN ${ }^{2}$
}

\begin{abstract}
Supply chain management philosophy proposes that business performance can be improved by embracing a systems approach in which supply chains are viewed as whole rather than independent members in a supply chain. Supply chain orientation is seen as a requirement for successful execution of supply chain management. Ports are an inseparable part of international trade and supply chains. As ports have a key role in supply chains it is very important to assess supply chain orientation and performance of ports from users' perspective. However, the literature analyzing supply chain orientation in port sector is limited. This research aims to analyze supply chain orientation level in one of the significant ports in terms of cargo handling in Turkey. Besides this port supply chain orientation and its effect on port performance from port users' perspectives is analyzed in this research. According to the findings, the level of supply chain orientation is moderate. Among supply chain orientation dimensions channel integrations mechanism effects service quality, customer orientation and service price where relationship with users effect only service quality and customer orientation.
\end{abstract}

Keywords: Port, Supply Chain Management, Supply Chain Orientation, Port Supply Chain Orientation, Port Performance

1 Lecturer, Mogadishu University, Department of Business Administration, Mogadishu, Somalia, hassanabdih@mu.edu.so, ORCID No: 0000-0002-54212848

${ }^{2}$ Asst. Prof., Trakya University, Department of Business Management, Edirne, Turkey, onurcetin@trakya.edu.tr, ORCID No: 0000-0003-1835-3333 


\title{
LIMAN TEDARIKK ZINCİII ORYANTASYONU VE PERFORMANSA ETKISI
}

\begin{abstract}
$\ddot{O} Z$
Tedarik zinciri yönetimi felsefesi tedarik zinciri içindeki üyelerin bağımsız olarak değil de sistem yaklaşımı içinde bir bütün olarak hareket etmesi sayesinde işletme performansının arttırllabileceğini öne sürmektedir. Tedarik zinciri yönetiminin başarılı bir şekilde uygulanması için tedarik zinciri oryantasyonunu bir gereklilik olduğu söylenebilir. Limanlar uluslararast ticaretin ve tedarik zincirlerinin ayrılmaz bir parçasıdır. Limanlar tedarik zincirinin önemli bir parçası olduğundan tedarik zinciri oryantasyonu ve performans değerlendirmesinin liman kullanıcıları tarafindan yapılması da önem arz etmektedir. Bununla birlikte limanlarda tedarik zinciri oryantasyonu ile ilgili çalışma sayısı sınırlıdır. Bu çalışma kargo elleçleme açısından Türkiye'nin en büyük limanlarından birisindeki tedarik zinciri oryantasyonu düzeyini ölçmeyi amaçlamaktadır Bunun yanında tedarik zinciri oryantasyonunun liman performansı üzerindeki etkisini incelemek diğer bir amaçtır. Bulgulara göre tedarik zinciri oryantasyonu düzeyi orta düzeyin biraz üstündedir. Bulgulara göre tedarik zinciri oryantasyonu boyutlarından kanal entegrasyon uygulamalart hizmet kalitesi, müssteri oryantasyonu ve hizmet fiyatı üzerinde etkili iken, kullanıc liman ilişkileri hizmet kalitesi ve müşteri oryantasyonu üzerinde etkilidir.
\end{abstract}

Anahtar Kelimeler: Liman, Tedarik zinciri yönetimi, Tedarik zinciri oryantasyonu, Liman tedarik zinciri oryantasyonu, Liman performansi.

\section{INTRODUCTION}

Most of the companies focused Supply Chain Management (SCM) concept after 1980's in order to improve their performance from several aspects. Mentzer et al. (2001) reported that SCM can be described from different points of view. They defined SCM; as a management philosophy, as a group of actions to act on the management philosophy and as a management process. SCM as a management philosophy includes the coordination of a supply chain from an overall system perspective, with each of the tactical activities of distribution flows seen within a broader strategic context. This is more precisely conceptualized as supply chain orientation (SCO).

Ports are seen as an inseparable part of the international trade and a vital component of supply chains. The main roles of a port include providing of shelter and safe anchorage for ships, handling cargo and passengers, facilitating ship docking and repair services, providing a hub that connects ships and what they transport to other supply chains networks of international trade (Branch, 1986: 1). 
Besides their functional roles, ports have a vital importance for supply chains (Robinson, 2002). The importance of ports in responding their customers in the supply chain has been increasing (Hall and Robbins, 2007; Mangan and Lalwani, 2008). Paixao and Marlow (2003) reported that level of integration of ports in supply chains should be increased. Analyzing SCO and performance in ports from the perspective of users has been gaining more importance (Lam and Song, 2013). Hence, SCO becomes more important for ports in order to give required service to user and increase their performance (Tongzon et al. 2009). Although the research regarding the impact of ports in SCM has been increasing, there has been a limitation in those researches focusing port SCO in particular and SCO in general. This paper aims to analyze the port SCO levels and its impact on port performance by studying the terminals of Turkish Ambarlı port from its users' perspectives.

The existing literature in Turkish seaport supply chain focuses on seaport logistics, privatization, competitiveness, and performance (Yıldırım and Deveci, 2016). Additionally, Ece (2015) surveyed opportunities regarding to logistic and supply chain integration of Turkish seaports. Still, efforts regarding SCO in ports from the practitioner's perspective and from the academia was constrained. The limitation on how Turkish ports embrace supply chain orientation in terms of evaluating SCO levels is significant in order to improve port performances. Hence, there is a need to fill the gap in Turkish seaport SCO in current literature.

The main question of the research is to what extent Turkish seaport supply chain is oriented, while considering this evaluation from port users' perspectives. Besides this, the other research question evaluates the relationship between SCO and performance in terms of effectiveness in Turkish seaport. This paper contributes to the literature by considering the terminals of Ambarl to evaluate the levels of supply chain orientation in the selected terminals, using constructs selected from existing literature. This paper differs from the previous empirical literature concerning Turkish ports by assessing the SCO levels and the relationship between $\mathrm{SCO}$ and performance for the first time and evaluating it from port users' perspectives.

\section{SUPPLY CHAIN ORIENTATION}

Mentzer et al. (2001) defined SCO as "the recognition by an organization of the systemic, strategic implications of the tactical activities involved in managing the various flows in a supply chain". While making a distinction between SCO and SCM concepts, it can be said that SCM can be viewed as a management philosophy inside the firm which means it has 
an inter-organizational perspective while $\mathrm{SCO}$ has an intra-organizational perspective (Mentzer et al. 2001). Management of flows in the SC is in the center of SCM while underlining strategic awareness and embracing of SCM within an individual supply chain firm is in the center of SCO (Esper et al. 2010). According to SCO definition of Mentzer et al. (2001).

The SCM philosophy proposed that business performance can be improved by embracing a systemic approach in which SC is viewed as whole and develops strategic collaboration with supply chain members with the aim of creating value for the customer (Patel et al. 2013: 716). $\mathrm{SCO}$ can be seen as a prerequisite for effective SCM. Both SCM and SCO constitute operational conceptualization of the generic SCM philosophy (Min et al. 2007: 508).

Moreover, SCO is the organizational philosophy in which businesses perceive systematic and strategic impact of tasks and processes involved in managing the numerous flows in a supply chain. Accordingly, a business can possess a SCO when the whole management team comprehends the impact of well-integrated and managed all flows of products, services, finances, and information between their suppliers and customers. SCO is a managerial philosophy in which businesses realize how supply chains are significant for business success. In this case, business develop a wider view of supply chain by considering their supplier' supplier and their immediate customer, the purchaser of their products and services to their end customer, the consumer of the products. By this generic focus of the whole supply chain system, companies aim to offering enhanced services and achieve high customer satisfaction levels (Shanmugan and Kabiraj, 2012: 45-46).

SCO has been defined from two different perspectives. The first one is strategic SCO which underlines supply chain flows and strategic direction of supply chain (Esper et al. 2010). The main aim is to compete with supply chain capabilities (Defee et al. 2009). Strategic SCO also emphasizes organizational artifacts that facilitates SCM. The second perspective is structural SCO represents organizational capabilities that support SCM. Structural SCO consists of behavioral elements such as trust, commitment, organizational compatibility, cooperative norms, and top management support Min et al. (2007). 


\section{SUPPLY CHAIN ORIENTATION AND PERFORMANCE}

Hult et al. (2008), have revealed that there is (two-way) relationship between performance and important factors of SCO such as customer, competitor, supplier, strategic and logistics orientation. Tinney (2012) also have reported that there is a relationship between $\mathrm{SCO}$ and cooperation and this relationship also affects company performance.

In the works of Shanmugan and Kabiraj (2012) has resulted that SCO is closely related with the performance components firms in supply chain such as trust, cooperation, customer orientation and information sharing. Sakagawa et al. (2018) showed that market orientation and strategic SCO had a significant impact on business performance. Subsequently, the results show that marketing capabilities serve as an intermediary between business performance and customer relationship management. Likewise, it has emerged that SCO, SC capacity and strategic objectives are aligned (Esper et al. 2010).

Research conducted by Davis-Sramek et al. (2019) has shown that a tendency towards SCO through global supplier sensitivity. Similarly, according to the findings of the work conducted by Sakagawa et al. (2018), market orientation and strategic SCO have a significant effect on business performance. According to the findings of the study conducted by Patel et al. (2013), strategic SCO and structural SCO contribute to the improvement of business performance. Relationships between strategic $\mathrm{SCO}$, structural $\mathrm{SCO}$ and firm performance are strengthened in dynamic environments.

Jadhav et al. (2018) have discovered that SCO, SC cooperation and communication can directly affect the environmental and social sustainability performance of the overall supply chain. The findings of the research on relationship between firm integration and SCO has shown that the internal integration of the firm depends on customer competitor, supplier, and logistics integration. Business-customer orientation is a significant component of SCO (Hamid and Sukati, 2011). In a related manner, the findings of the research conducted by Jüttner and Christopher (2013) showed that marketing orientation contributes to the effectiveness in structural and strategic dimensions of SCO.

The results of the works of Esper et al. (2010) supply chain orientation can be achieved by harmonizing the SC capacity and strategic objectives of the enterprise. According to the findings of the research on SCM and sustainable development projects conducted by Diniz and Fabbe- 
Costes (2007) indicated that the lack of coherent SCM and SCO is one of the reasons why regional sustainability projects fail.

Moreover, SCO and supply relationship management have shown a positive impact on organizational purchasing effectiveness (Miocevic and Crnjak-Karanovic, 2012). Correspondingly, Omar et al. (2012) has shown that SCO is a complex process. In their examination about manufacturersupplier integration and revealed that the expectations of manufacturers and suppliers are different. According to the findings of the study conducted by there is a relationship between the SCO and cooperation. This relationship also affects firm performance (Tinney, 2012).

\section{SUPPLY CHAIN ORIENTATION IN PORTS}

Research mentioned above are conducted in different sectors however SCO research in port sector is limited. Gaurav (2004) and Ducruet et al. (2010) mentioned the tendency about SCO and supply chain integration (SCI) in port sector. Tongzon et al. (2009) developed a survey questionnaire based on the studies of Panayides and Song (2007) and Song and Panayides (2008). Tongzon et al. (2009) operationalized SCO components for ports as: relationship with users (RWU), value added services (VAS), inter-connecting intermodal infrastructure (ITM) and channel integration services (CIS). This research is built upon these dimensions of SCO for ports as developed by Tongzon et al. (2009). However, Tongzon et al. (2009) declares that the concept of SCO definition of Mentzer et al. (2001) encompasses the concept of SCI. So the research is associated with SCI as well.

The first component of SCO is RWU. The relationship between the port in a supply chain and its users such as shipping lines begins with cooperation. Establishing a long-term relationship with the users of the port creates significant potential for port performance. The second factor of SCO is VAS. VAS can be defined as logistics activities that add value to customers or users. (Tongzon et al. 2009).

The third factor of SCO is ITM. ITM is about connectivity of ports with other transportation modes, especially roads and railways (Tongzon et al., 2009). ITM or combined transport is transport using at least two modes of transport, such as road, air, sea, and rail, in order to deliver goods to the buyer. Mixed transport is generally carried out through the operators that organize transport operations. Mixed transportation is commonly carried out using containers (Şen, 2008: 27). 
The final component of SCO is CIP. This term incorporates the degree to which port administration teams up with different individuals from the supply chain keeping in mind the end goal to achieve costeffectiveness and higher performance throughout the supply chain framework (Tongzon et al. 2009).

Research regarding SCO for ports are very limited. Tongzon et al. (2009) measured SCO from both terminal operators and user's perspective using RWU, VAS, ITM and CIP constructs. Woo et al. (2013) searched the relationships between SCI, SCO and performance in port sector using SCI and SCO together. SCO is operationalized as top management support, human resources, financial resources, and relationship orientation. SCI is operationalized as information and communication systems, long term relationships, VAS, inter modal transport services and supply chain integration practices. In their model SCO is antecedent of SCI. Performance is measured from two aspects; effectiveness and efficiency Woo et al. (2013) concluded that SCO has a significant effect on SCI.

In port sector research regarding SCI are more frequent than SCO. Panayides and Song (2008) defined terminal supply chain integration (TESCI). TESCI is consists of information and communication systems (ICS); VAS; multimodal systems and operations; and supply chain integration practices. Tseng and Liao (2015) searched SCI in container shipping firms. They reported that SCI provides higher operation efficiency and obtains an enhanced performance improvement. Yuen and Thai (2017) reported five barriers on SCI in port sector. These were trust and commitment, resistance to change, inadequate supply chain leadership, lack of resources and inadequate measurement. Yuen et al. (2019) reported that the relationship between critical success factors of SCI, SCI and performance were significant in port sector. In Turkey context Kurtuluş et al. (2016) measured the integration level of three Aegean terminals according to port user companies' perceptions. They used port supply chain integration (PSCI) with four constructs: RWU, ICS, VAS and multimodal connections and systems from port users' perspective.

\section{RESEARCH METHODOLOGY}

Research on Turkish seaport supply chain orientation and its relationship with performance is inadequate. A review in the literature concerning Turkish seaport supply chain orientation showed that. This paper is inspired by the theoretical framework developed by Panayides and Song (2008) in order to conceptualize seaport supply chain orientation. This framework has suggested certain constructs to constitute port orientation in the supply chain which RWU, VAS, ITM and CIP. The 
research first aims to determine the SCO level the seaport terminals selected for the study. Additionally, this research aims to analyze the relationship between SCO and performance.

This paper employs a convenience sampling method to select participants of this study since it is one of the easiest sampling methods, as participants are selected based on availability and willingness participate in the study. A survey questionnaire is used to collect data from the companies that use Ambarlı port terminals. These respondents were operations department managers of shipping lines, transportation agents and logistic companies. A total of 64 questionnaires were obtained and 57 of them can be used. SCO scale was a Likert-scales ranging from 1: strongly disagree to 5: strongly agree.

The port of Ambarl is located in Istanbul and considered one of the Turkey's significant ports. It is one of the most important pots in Turkey according to cargo handling quantity conducted in last five years (20152019) (https://atlantis.udhb.gov.tr/istatistik/istatistik konteyner.aspx). The port of Ambarl1 shares the same location with several terminals and facilities such as Marport, Kumport, Mardaş and Akçansa. This port facility, which is shared by different terminals, operates under the name of Ambarl1 Port Facility (ALTAŞ Port). The port settlement area is an important industrial region with general management, infrastructure, planning, security and environmental regulation sections (Mermutlu et al. 2012). The Ambarlı Port Region has a service domain that accommodates approximately 20 million people. Since this port is located in a strategic position in Istanbul, Turkey's largest city and its commercial and industrial in the capital city, it gives more opportunity for investment of all kinds. Ambarlı port complex is a key position in foreign trade with its large service domain dominated by Istanbul and its large population. Moreover, Ambarl is at the intersection of rich trade routes. The Port of Ambarl1 is connected to TEM and E-5 highways. The Ambarl1 Harbor complex dominates the trade routes due to its location in the Marmara Sea on the way to the Aegean and Black Sea seas (Biber, 2014).

In order to measure the SCO for ports, this paper used a SCO scale which includes 20 items and developed by Tongzon et al. (2009) based on the constructs developed by Panayides and Song (2007), Song and Panayides (2008). Items of SCO scale used in this research are the same with the research of Tongzon et al. (2009). While Tongzon et al. (2009) used a seven-point Likert scale, in this research five-point Likert scale is used. The constructs in the scale are RWU, VAS, ICIS and CIP. In addition, a port performance scale developed by Woo et al. (2008) and used in Woo (2010) is used to measure the port performance. Woo (2010) 
measured performance from two aspects: effectiveness and efficiency. The port performance scale used in this research used effectiveness aspect. Effectiveness is based on three components "service quality" (SQ), "customer orientation" (CO) and "service price" (SP). Performance scale consists of 13 items and they can be found in the research of Woo (2010). This scale is a five-point Likert scale as well. Scales can be seen in the Appendix as well.

The aim of this study was to determine the levels of seaport SCO in the selected port and analyze how the SCO dimensions of RWU, VAS, ITM, and CIP on port performance dimensions of SQ, CO and SP which represent effectiveness. As a result, the study employs three models to analyze the effect of SCO factors on the three port performance factors. For each performance factor one model is developed. In each model independent variables are RWU, VAS, ICIS, and CIP.

According to the three distinct models created, this study conducts analysis along the lines of these hypotheses:

$\mathrm{H}_{1 \mathrm{a}}$ : RWU has a significant effect on SQ.

$\mathrm{H}_{1 \mathrm{~b}}$ : VAS has a significant effect on SQ.

$\mathrm{H}_{1 \mathrm{c}}$ : ICIS has a significant effect on SQ.

$\mathrm{H}_{1 \mathrm{~d}}$ : CIP has a significant effect on SQ.

$\mathrm{H}_{2 \mathrm{a}}$ : RWU has a significant effect on CO.

$\mathrm{H}_{2 b}$ : VAS has a significant effect on CO.

$\mathrm{H}_{2 \mathrm{c}}$ : ICIS has a significant effect on $\mathrm{CO}$.

$\mathrm{H}_{2 \mathrm{~d}} \mathrm{CIP}$ has a significant effect on $\mathrm{CO}$.

$\mathrm{H}_{3 \mathrm{a}}$ : RWU has a significant effect on SP.

$\mathrm{H}_{3 \mathrm{~b}}$ : VAS has a significant effect on SP.

$\mathrm{H}_{3 \mathrm{c}}$ : ICIS has a significant effect on SP.

$\mathrm{H}_{3 \mathrm{~d}} \mathrm{CIP}$ has a significant effect on SP. 


\section{DATA ANALYSIS AND FINDINGS}

To analyze data, the study employed SPSS 23 . Before delving into the more detailed statistical analysis, demographic characteristics of the respondents and the companies they represent is presented.

Table 1: Demographic findings

\begin{tabular}{|c|c|c|c|c|c|}
\hline \multicolumn{2}{|c|}{ Work experience } & \multicolumn{2}{|c|}{$\begin{array}{l}\text { Company Experience } \\
\text { (Industry Expertise) }\end{array}$} & \multicolumn{2}{|c|}{ Full time employees } \\
\hline Years & Percent & Years & Percent & Employee & Percent \\
\hline $1-3$ & 33.3 & $1-5$ & 32.2 & $1-50$ & 8.7 \\
\hline $4-6$ & 24.2 & $6-10$ & 16.9 & $51-100$ & 37.0 \\
\hline $7-9$ & 21.2 & $11-15$ & 16.9 & $101-250$ & 32.6 \\
\hline 10 & 6.1 & $16-20$ & 12.3 & $251+$ & 21.7 \\
\hline $10+$ & 15.2 & $21+$ & 21.5 & & \\
\hline
\end{tabular}

As it can be seen in Table 1, 33\% of the respondents have less than 4 years of experience and most of the respondents have less than 10 years of experience.

Corresponding to the questions related to the respondent companies' industry experience, a total of $50.7 \%$ have industry experience of more than 11 years. Also, $16.9 \%$ of the respondent companies have 610 years of industry expertise, while the rest has $1-5$ years of industry experience.

With regards the validity of the SCO constructs, an Explanatory or Confirmatory Factor Analysis is carried on. Explanatory Factor Analysis can be performed to determine whether the items are exactly included under the dimensions. To conduct an Explanatory Factor Analysis, the number of samples should be at least 5 times the number of items (Hair et al., 2014: 100).

According to Shah and Goldstein (2006) a median sample size may be about 200 cases based on reviews of studies in different research areas, including operations management. In structural equation models it is recommended that the ratio of the number of cases $(N)$ to the number of model parameters that require statistical estimates $(q)(N: q)$ should be (10:1). Besides this with $N<100$, almost any type of SEM may be untenable unless a remarkably simple model is analyzed (Kline, 2015: 16). In this research there are 33 items, and the sample size is 57 . Since these conditions was not fulfilled and the scales used were subjected to Explanatory or Confirmatory Factor Analysis conducted previously, no new factor analysis was performed. Meanwhile, Panayides and Song 
(2008), Song and Panayides (2008) conducted an Exploratory Factor Analysis to validate the SCO measurement model, while Tongzon et al. (2009) thought it is sufficient to conduct a Confirmatory Factor Analysis in their studies of Korean Incheon port and validated the constructed of SCO used in this work.

Initially, items are analyzed according to their means, standard deviations, kurtosis, and skewness values. Mean values of items were between 3,089 and 3,759 which indicates that overall SCO is slightly above the midpoint 3. Kurtosis and skewness values were in the range of $(-1,5,+1,5)$ which was recommended for normal distribution. The extent of supply chain orientation as perceived by users of Ambarlı port terminals from the responses tabulated in Table 2 in averages. The averages of four key constructs on which supply chain orientation is based indicated a value of 3.4 and above on the 5-point Likert scale. Any item or construct did not have a mean more than 4 and this shows that shipping lines in overall have not perceived the terminals supply chain oriented. However, it can be said that there is a tendency regarding supply chain orientation. The highest scores were about the items "adequate connectivity for the ship road interface" and the lowest item was "adequate connectivity for ship rail interface". The second lowest score was about the item was about ship rail operations.

Although these levels of SCO seem to be low. It gives a hint that ports have SCO tendencies. Moreover, both RWU and VAS has the highest averages, while ICIS and CIP have lower averages.

The averages of the $S C O$ and $P P$ constructs contain clues regarding the supply chain orientation and port performance levels. Since the evaluation statements are made on a 5-point Likert scale, the averages of above 3 in the Table 2 indicate that ports maintain similar $S C O$ and $P P$ levels.

To confirm the reliability (the internal consistency of the items that are used to measure a latent construct) of the SCO and PP scale used in this paper, the constructs are tested through Cronbach's Alpha.

Table 2 presents reliability test results of both $S C O$ and $P P$ constructs. For instance, $S C O$ constructs of RWU, VAS, ITM and CIP have a Cronbach's Alpha values of 0.803, 0.702, 0.726, and 0.778, respectively. On the other hand, PP constructs of SQ, CO and SP main a Cronbach's Alpha values of $0.785,0.818$ and 0.842 , respectively. 
Table 2: Reliability test of the variables

\begin{tabular}{lll|l}
\hline Factors & $\begin{array}{c}\text { Cronbach's } \\
\text { Alpha }\end{array}$ & Mean & $\begin{array}{c}\text { Standard } \\
\text { Deviation }\end{array}$ \\
\hline $\boldsymbol{S C O}$ & \multicolumn{3}{|c}{} \\
\hline RWU & 0.803 & 3.500 & 0.779 \\
VAS & 0.702 & 3.502 & 0.683 \\
ICIS & 0.726 & 3.428 & 0.681 \\
CIP & 0.778 & 3.475 & 0.799 \\
SQ & 0.785 & 3.691 & 0.667 \\
CO & 0.818 & 3.497 & 0.799 \\
SP & 0.842 & 3.451 & 0.793 \\
\hline
\end{tabular}

Correlation between constructs is analyzed and demonstrated in Table 3. RWU, VAS, ITM and CIP are correlated with SQ, CO and SP significantly. Table 3 indicates a relationship between each SCO dimension and each PP dimension. In other words, each of SCO dimensions separately are associated with SQ, CO and SP.

Table 3: Correlations between variables

\begin{tabular}{l|ccccccc} 
& RWU & VAS & ICIS & CIP & SQ & CO & SP \\
\hline RWU & 1 &, $707^{* *}$ &, $421^{* *}$ &, $565^{* *}$ &, $706^{* *}$ &, $598^{* *}$ &, $463^{* *}$ \\
VAS &, $707^{* *}$ & 1 &, $607^{* *}$ &, $634^{* *}$ &, $626^{* *}$ &, $530^{* *}$ &, $505^{* *}$ \\
ICIS &, $421^{* *}$ &, $607^{* *}$ & 1 &, $620^{* *}$ &, $558^{* *}$ &, $498^{* *}$ &, $418^{* *}$ \\
CIP &, $565^{* *}$ &, $634^{* *}$ &, $620^{* *}$ & 1 &, $644^{* *}$ &, $613^{* *}$ &, $647^{* *}$ \\
SQ &, $706^{* *}$ &, $626^{* *}$ &, $558^{* *}$ &, $644^{* *}$ & 1 &, $755^{* *}$ &, $581^{* *}$ \\
CO &, $598^{* *}$ &, $530^{* *}$ &, $498^{* *}$ &, $613^{* *}$ &, $755^{* *}$ & 1 &, $654^{* *}$ \\
SP &, $463^{* *}$ &, $505^{* *}$ &, $418^{* *}$ &, $647^{* *}$ &, $581^{* *}$ &, $654^{* *}$ & 1 \\
$* *=\mathrm{p}<0,01$ & & & & & & &
\end{tabular}

To analyze the impact of SCO dimensions together on SQ, a stepwise regression analysis is conducted. According to the results the model was significant $(\mathrm{F}=38.254$ and $\mathrm{p}=0,000)$ with an $\mathrm{R}^{2}$ of 0,571 . Results indicate that RWU $(\mathrm{p}=0,000)$ and $\mathrm{CIP}(\mathrm{p}=0,001)$ affected SQ significantly while VAS and ICIS did not have any significant effect. According to the results of regression analysis of the first model, the hypotheses $\mathrm{H}_{1 \mathrm{a}}$ and $\mathrm{H}_{1 \mathrm{~d}}$ are supported and $\mathrm{H}_{0}$ hypotheses are rejected for these two hypotheses. $\mathrm{H}_{1 \mathrm{~b}}$ and $\mathrm{H}_{1 \mathrm{c}}$ hypotheses are not supported.

To analyze the impact of SCO dimensions together on $\mathrm{CO}$, a stepwise regression analysis is conducted. According to the results the model was significant $(\mathrm{F}=23.848$ and $\mathrm{p}=0,000)$ with an $\mathrm{R}^{2}$ of 0,449 . Results indicate that RWU $(p=0,001)$ and CIP $(p=0,003)$ affected SQ significantly while VAS and ICIS did not have any significant effect. As shown by the 
results of regression analysis of the second model, the hypotheses $\mathrm{H}_{2 \mathrm{a}}$ and $\mathrm{H}_{2 \mathrm{~d}}$ are supported.

To analyze the impact of SCO dimensions together on SP, the study conducted a stepwise regression analysis. According to the results the model was significant $(F=39,684$ and $p=0,000)$ with an $R^{2}$ of 0,409 . Results indicate that only CIP $(p=0,000)$ affected SQ significantly while RWU, VAS and ICIS did not have any significant effect. As shown by the results of regression analysis of the second model, only hypothesis $\mathrm{H}_{3 \mathrm{~d}}$ is supported.

\section{DISCUSSION AND CONCLUSIONS}

Literature regarding SCO for ports are limited especially in Turkey and for this reason this research aimed to analyze the degree of SCO and performance in port sector from the perspective of shipping lines.

The overall average of seaport SCO is just above the midpoint on the 5-point Likert scale. Generally, the SCO level was moderate and RWU and VAS has the highest values among all SCO constructs. ITM and CIP have lower scores than VAS and RWU. However, scores of all SCO constructs were similar and close and just above the midpoint. Similar results are seen in the works of Tongzon et al. (2009) where RWU has the highest mean value and it was above midpoint. Tongzon et al. (2009) reported that the mean of SCO level for port users was 4.0 out of 7 . Woo et al. (2013) reported that the mean scores of SCO dimensions were lower than 4 in a 7-point Likert scale. According to Woo et al. (2013) the level of VAS was moderate and according to Tongzon, et al. (2009) VAS was near to 4 in a 7-point Likert scale. However, in this research the value of VAS is slightly above the midpoint. When compared with the literature, this research reported similar findings which indicates a moderate level of SCO. The relationship with port users is sufficient when compared with other ports (Tongzon et al. 2009; Woo et al. 2013).

The items which has lowest scores was about ship rail connectivity and ship rail operations. This shows a general inadequacy regarding ship rail infrastructure and operations.

When it comes to PP levels, it can be said that SCO levels were remarkably close to PP levels and all were slightly above the average. This shows that likewise SCO, PP levels should be improved. The scores of CO and SP are lower than SQ, which indicates terminal operators should focus more on $\mathrm{CO}$ and SP. 
The results of a stepwise regression analysis revealed that SCO constructs of RWU and CIP has a statistically significant effect on port performance constructs of SQ and CO. The only SCO dimension that affects SP was found to be CIP. It has been found that SCO significantly affects port performance. However, the most important components of SCO regarding performance are RWU and CIP.

Port SCO performance relationship found in this research is conssitent with the research in the literature (Shanmugan and Kabiraj, 2012; Patel et al., 2013; Sakagawa et al., 2018).

It is important that port operators monitor supply chain orientation degrees based on the perceptions of their customers (especially transport lines and transporters). Since the supply chain orientation levels of the ports are not very high, the ports should apply SCO philosophy in their operations so that both their performance and the performance of other members in the supply chains in which they operate increases.

The findings of this study have shed more light on the level of SCO and its relationship with performance regarding the Ambarl terminals from the perspective of its users. The moderate level of seaport SCO orientation is an indication that seaport management can work on adopting SCM philosophy in a more rigorous way.

Literature on seaport supply chain orientation could obtain new perspectives on evaluating how well the Turkish ports embrace SCO. Future research on Turkish ports regarding SCO and SCI can help gather more information on this issue that this study could not delve more deeply by of time and resources. One of the constraints of the research is the sample size. Besides this, performance is measured from effectiveness aspect.

In future researches, larger sample sizes, $\mathrm{SCO}$ and performance from both effectiveness and efficiency, from port users and terminal aspects can be analyzed. Furthermore, similar research can be conducted using SCO dimensions in other ports in order to compare the results with this research. Furthermore, SCO dimensions and performance can be measured in other ports in order to make performance comparison.

\section{ACKNOWLEDGEMENTS}

Thanks to Prof. Dr. Soner Esmer for his intellectual contribution. 


\section{REFERENCES}

Biber, G. (2014). Marmara bölgesi konteyner terminallerinde gerçekleşen ticarette tekirdağ asyaport limanı'nın sahip olacağı payın incelenmesi. Yüksek Lisans Tezi, Namık Kemal Üniversitesi, Sosyal Bilimler Enstitüsü, Tekirdağ.

Branch, A.E. (1986). Elements of Port Operations and Management. London: Chapman and Hall Ltd.

Davis-Sramek, B., Omar, A. and Germain, R. (2019). Leveraging supply chain orientation for global supplier responsiveness: The impact of institutional distance. The International Journal of Logistics Management, 30(1), 39-56.

Defee, C.C., Stank, T.P., Esper, T.L. and Mentzer, J.T. (2009). The role of followers in supply chains. Journal of Business Logistics, 30(2), 65-84.

Diniz, J. D. and Fabbe-Costes, N. (2007). Supply chain management and supply chain orientation: Key factors for sustainable development projects in developing countries? International Journal of Logistics Research and Applications, 10(3), 235-250.

Ducruet, C., Rozenblat, C. and Zaidi, F. (2010). Ports in multi-level maritime networks: Evidence from the Atlantic (1996-2006). Journal of Transport Geography, 18(4), 508-518.

Ece, N.J. (2015). Küresel konteyner terminal operatörlerinin tedarik zincirinin entegrasyonu ve yönetimine ilişkin stratejileri: Türk limanları için firsatlar. In: 2. Ulusal Liman Kongresi. Izmir, Turkey.

Esper, T.L., Clifford D.C. and Mentzer, J.T. (2010). A framework of supply chain orientation. The International Journal of Logistics Management, 21(2), 161-179.

Gaurav R. (2004). Closed loop transport management. Logistics \& Transport Focus, 6(9), 44-7.

Hair, J.F., Black, W.C., Babin, B.J. and Anderson, R.E. (2014). Multivariate Data Analysis. (Seventh Edition). England: Pearson.

Hall, P.V. and Robbins, G. (2007). Which Link, in Which Chain? Inserting Durban into Global Automotive Supply Chains, in Wang, J., Olivier, D., 
Notteboom, T. and Slack, B. (Ed.), Ports, Cities and Global Supply Chains, pp. 221-231. England: Ashgate.

Hamid, A.B.A. and Sukati, I. (2011). The relationship between firm integration and supply chain orientation. Journal Kemanusiaan, 9(1), 3356.

Hult, G.T.M., Ketchen Jr., D.J., Adams, G.L. and Mena, J.A. (2008). Supply chain orientation and balanced scorecard performance. Journal of Managerial Issues, 20(4), 526-544.

Jadhav, A., Orr, S. and Malik, M. (2018). The role of supply chain orientation in achieving supply chain sustainability. International Journal of Production Economics, 217, 112-125.

Jüttner, U. and Christopher, M. (2013). The role of marketing in creating a supply chain orientation within the firm. International Journal of Logistics Research and Applications, 16(2), 99-113.

Kline, R.B. (2015). Principles and Practice of Structural Equation Modeling. (Fourth Edition). New York: The Guilford Press.

Kurtuluş, E., Çetin, Ç.K. and Deveci, D.A. (2016). Türkiye'nin Ege bölgesindeki konteyner terminallerinin tedarik zincirlerine entegrasyonu. Dokuz Eylül Üniversitesi Denizcilik Fakültesi Dergisi, 8(1), 159-179.

Lam, J.S.L. and Song, D.W. (2013). Seaport network performance measurement in the context of global freight supply chains. Polish Maritime Research, 20, 47-54.

Mangan, J. and Lalwani, C. (2008), Port-centric logistics. International Journal of Logistics Management, 19(1), 29-41.

Mentzer, J.T., DeWitt, W., Keebler, J.S., Min, S., Nix, N.W., Smith, C.D. and Zacharia, Z.G. (2001). Defining Supply Chain Management. Journal of Business Logistics, 22(2), 1-25.

Mermutlu, E., Mahmutoğlu, Y. and Şans, G. (2012). İstanbul-Ambarl1 heyelanının izlenmesi ve analizi. In: 65. Türkiye Jeoloji Kurultayı. İstanbul, Turkey.

Min, S., Mentzer, J.T. and Ladd, R.T. (2007). A market orientation in supply chain management. Journal of the Academy of Marketing Science, 35(4), 507-522. 
Miocevic, D. and Crnjak-Karanovic, B. (2012). The mediating role of key supplier relationship management practices on supply chain orientation The organizational buying effectiveness link. Industrial Marketing Management, 41(1), 115-124.

Omar, A., Davis-Sramek, B., Fugate, B.S. and Mentzer, J.T. (2012). Exploring the complex social processes of organizational change: supply chain orientation from a manager's perspective. Journal of Business Logistics, 33(1), 4-19.

Paixao, A.C. and Marlow, P.B. (2003). Fourth generation ports- a question of agility? International Journal of Physical Distribution and Logistics Management, 33(4), 355-376.

Panayides, P.M. and Song, D.W. (2007). Development of a measurement instrument for port supply chain orientation. In: Proceedings of the IAME 2007 Annual Conference. Athens, Greece.

Panayides, P.M. and Song, D.W. (2008). Evaluating the integration of seaport container terminals in supply chains. International Journal of Physical Distribution \& Logistics Management, 38(7), 562-584.

Patel, P.C., Azadegan, A. and Ellram, L.M. (2013). The effects of strategic and structural supply chain orientation on operational and customerfocused performance. Decision Sciences, 44(4), 713-753.

Robinson, R. (2002). Ports as elements in value-driven chain systems: the new paradigm. Maritime Policy \& Management, 29 (3), 241-255.

Sakagawa, Y., Kajalo, S. and Morimura, F. (2018). The impact of market orientation and supply chain orientation on business performance in Japanese retailing. In: 2018 Global Marketing Conference at Tokyo, 14831486. Tokyo, Japan.

Shah, R. and Goldstein, S.M. (2006). Use of structural equation modeling in operations management research: Looking back and forward. Journal of Operations Management, 24(2), 148-169.

Shanmugan, J. and Kabiraj, S. (2012). A case study approach for understanding supply chain orientation in Indian pharmaceutical firms. Kuwait Chapter of the Arabian Journal of Business and Management Review, 1(9), 45-78. 
Song, D.W. and Panayides, P.M. (2008). Global supply chain and port/terminal: Integration and competitiveness. Maritime Policy \& Management, 35(1), 73-87.

Şen, A. (2008). Tedarik zinciri yönetiminde soğuk lojistik uygulamarının etkinliğinin arttırlmasına yönelik bir çalışma. Yüksel Lisans Tezi, Dokuz Eylül Üniversitesi, Sosyal Bilimler Enstitüsü, Izmir.

Tinney, J.M. (2012). The effects of supply chain orientation, supply chain management, and collaboration on perceived firm performance. Graduate Research Project Report, Air Force Institute of Technology, Ohio, USA.

Tongzon, J., Chang, Y.T. and Lee, S.Y. (2009). How supply chain oriented is the port sector? International Journal of Production Economics (122), 21-34.

Tseng, P.H. and Liao, C.H. (2015). Supply chain integration, information technology, market orientation and firm performance in container shipping firms. The International Journal of Logistics Management 26(1), 82-103. Woo, S.H. (2010). Seaport supply chain integration and orientation, and their impact on performance. PhD Thesis, Cardiff University, UK.

Woo, S.H., Pettit, S.J. and Beresford, A.K. (2013). An assessment of the integration of seaports into supply chains using a structural equation model. Supply Chain Management: An International Journal, 18(3), 235252.

Woo, S.H., Pettit, S.J. and Beresford, A.K.C. (2008). A new port performance measurement framework in a changing logistics environment. In: Proceedings of the LRN 2008 Annual Conference. Liverpool, UK.

Yıldırım, C. and Deveci, D.A. (2016). Denizyolu taşımacılığının tedarik zinciri ile entegrasyonu: Kaynak taraması ve gelecek araştırmalar için öneriler. Dokuz Eylül Üniversitesi Denizcilik Fakültesi Dergisi, 8(1), 3282.

Yuen, K.F. and Thai, V. (2017). Barriers to supply chain integration in the maritime logistics industry. Maritime Economics \& Logistics, 19(3), 551572.

Yuen, K. F., Wang, X., Ma, F., Lee, G. and Li, X. (2019). Critical success factors of supply chain integration in container shipping: an application of resource-based view theory. Maritime Policy \& Management, 46(6), 653668. 


\section{APPENDICES}

\section{APPENDIX I}

SCO Scale (Tongzon et al. 2009).

1. The port views us as a strategic partner in mutually designing the flow of goods and information

2. Our relationship with the port is more based on mutual trust rather than on contractual obligations

3. We work together with the port to ensure higher quality of service

4. We work together with the port to reduce costs.

5 . The port frequently measures and evaluates user satisfaction.

6. The port has adequate facilities for adding value to cargoes (e.g. preassembly, manufacturing, packaging)

7. The port has the capacity to provide the widest possible road/rail access to hinterland and foreland.

8 . The port has the capacity to launch new tailored services should the need arise.

9. The port has a variety of services to handle the transferring of cargo from one mode to another.

10. The port has the capacity to convey cargo through the most diversified routes/modes at the least possible time to end-users premises.

11. The port has the capacity to deliver even more tailored services to different market segments.

12. The port/terminal has adequate connectivity for the ship/road interface.

13. The port/terminal has adequate operability for ship/road operations.

14. The port/terminal has adequate connectivity for the ship/rail interface.

15. The port/terminal has adequate connectivity for ship/rail operations.

16. The port collaborates with other channel members (e.g. shipping lines) to plan for greater channel optimization.

17. The port seeks to identify other competing channels for cargoes that might flow through the port.

18. The port benchmarks the logistics options available for cargoes that will flow through the port vis-a-vis alternative routes via competing ports. 19. The port seeks to identify least cost options for the transport of cargoes to hinterland destinations.

20 . The port constantly evaluates the performance of the transport modes available for linking its terminal to its hinterland destinations. 


\section{APPENDIX II}

Port Performance Scale (Woo, 2010)

1. Terminals in the ports provide a consistent reliable service.

2. Terminals in the ports handle cargoes on quoted or anticipated time.

3. Terminals in the ports handle cargoes on customers' time requirements.

4. Service lead-time of terminals in the ports is appropriate.

5. Annual number of com plaints from customers.

6. Terminals in the ports provide shipment information accurately.

7. Terminals in the ports respond promptly to the need of customers.

8. Terminals in the ports have quick decision making process.

9. Terminals in the ports are flexible in term s of volume and type of cargo handling.

10. Terminals in the ports deal with unexpected events or situations well.

11. Total service price of terminals in the port is competitive.

12. Cargo handling charge of terminals in the ports is competitive.

13. Charge for auxiliary services of terminals in the ports is competitive. 